\title{
阪神大震災を契機とする記録ボランティア活動の勃興と変遷 〜社会変動の観点からみたその意義と可能性についての考察
}

\author{
八ッ塚 一 郎 \\ 熊本大学
}

\section{要 約}

阪神・淡路大震災（1995）を契機として発生し分離・変容を遂げた，被災地におけるひとつのボランティ ア活動の系譜を報告した。さらに，社会的表象論を援用してこの事例を検討し，震災を契機とする社会変動 の構図と，それに対してボランティア実践が持つ意義とを考察した。(1)阪神大震災地元 NGO 救援連絡会議, (2)震災・活動記録室，(3)震災しみん情報室，(4)震災・まちのアーカイブ，(5)市民活動センター神戸，という 一連の団体は，被災地における情報の交換や伝達，記録資料の保存など，記録に関わるボランティアとして その活動を展開してきた。被災者の支援と被災体験の継承を企図して開始された記録活動は，復興に伴う被 災地域の変化のなかで一時その目的を喪失し停滞に陥った。その後, 団体の分裂と目的の特化により, 活力 を回復し現在に至っている。震災復興という状況における，記録活動，および，その変遷の意味を検討した。 あわせて, 社会変動へとつながる実践活動のあり方についても考察を行った。

キーワード : ボランティア, 社会変動, 社会的表象, 記録活動

\section{1. 問 題}

\section{1-1. 本稿の目的}

本稿の目的は，阪神・淡路大震災（1995）を契機とし て勃興した記録するボランティアの活動と, その変遷の 過程を手がかりとして, ボランティア実践と社会変動と の相互連関の構図を検討し, あわせて実践的活動への示 唆を導き出すことである。なお，本稿でいう記録するボ ランティアとは, 直接的な対面的活動や身体的労働活動 ではない活動に主として従事するボランティア活動のこ とを指す。すなわち, 直接的な活動の領域から一歩離れ て，ボランティア活動に関する記録や資料を作成・保存 したり, それらを用いた連絡調整や相互のやりとりに従 事したりするボランティア活動のことを指す。

阪神大震災（以下同様に略記）は, 日本社会における 「ボランティア」普及の大きな契機であった。災害救援で 注目を集めたボランティアは, 現在では, 福祉, 医療, 教育文化, 地域活動など, 幅広い分野へと浸透している。
また，震災ボランティアの活動は，1998 年の「NPO 法 (特定非営利活動促進法)」成立にも大きな影響を与えた。

阪神大震災以来, ボランティアは普及と興隆の一途を たどっているように見える。たとえば，全国社会福祉協 議会（2004）によると, ボランティアに参加する人々の 数は, 1980 年代以降, 一貫した増加傾向にある（80 年 代には 300 万人台だったものが, 1995 年に 500 万人を超 え, 98 年には 600 万人台に到達)。新聞記事においても, 「ボランティア」という語は, 1995 年を契機に使用量の 突発的な増加を示しており, 直後の一時的な落ち込みこ そあったものの一貫した増加を続けている（Yatsuzuka, 1999; 2003 等)。人員, および, 報道量の面からみると, ボランティアは広く社会に浸透し続けているといえる。

このような傾向をみると, 市民参画型社会一一多くの 人々が社会的課題に率先して関与寸る社会一几の変化 が着実に進みつつあるようにも見える。実際, ボランティ アに社会変革の希望を見出寸議論は震災以降数多く提起 されてきた（たとえば, 本間・出口（1996）, 吉永 (1999), 
立木（2001）など）。また 2000 年には「ボランティアが 深める好縁」と題された国民生活白書（経済企画庁, 2000）が刊行され，政府刊行物にもその存在が取り上げ られるようになっている。

このように, ボランティアを肯定的に評価し, 社会を 変革する存在と位置づける議論が高まる一方で, それに 対する懸念の声もある。すなわち, ボランティアの普及 といっても, それが社会構造の根本的な変化を招来して いるわけではない。それどころか, ボランティアの普及 そのものが, 旧来の社会体制を温存している, という議 論がそれにあたる。

たとえば, 2000 年における日本の市民団体の国内総生 産額は，全産業の $0.08 \%$ にどまっているとされる。ま た多くの NPO 法人は零細な規模にとどまっており, 職 員の給与水準も非常に低い（以上，山内 (2002))。ボラ ンティアの普及は話題になるものの, 市民による活動が, 大きな影響力を持った社会的勢力となっているかどうか には疑問が残る。

むしろ現今の状況は, ボランティアという無料の労働 力を, 行政体が便利使いしているだけに過ぎないのでは ないか，という問題提起もある。たとえば，中野（2001） によれば,「ボランタリーな活動というのは, 国家システ ムを超えるというよりは, むしろ, 国家システムにとっ て，コストも安上がりで実効性も高いまことに巧妙なひ とつの動員のかたちでありうる」(p.258)。すなわち, ボ ランティアは既存の社会体制に無償で奉仕・貢献してい るに過ぎない。そうであるならば，ボランティアの普及 は，旧来の社会構造をむしろ温存しているだけだという ことになる。であるならば, 上述の国民生活白書などは， ボランティアを動員し活用しようとする政策的意図のあ らわれであるのかもしれない。

注目すべきは，このような事態に対する予見と警戒の 念が，阪神大震災時のボランティアの現場において，す でに表明されていたという点である。たとえば，後述す る阪神大震災地元 NGO 救援連絡会議の代表であった草 地賢一氏は,「ボランティアは行政の下請けであってはな らない」ことを, 1995 年当時, 震災救援活動の最中に繰 り返し説いている。市民自身の自発的な活動が, 既存の 社会構造のもとに動員され回収されてしまうことへの懸 念は, かつての震災の渦中においても, 実際的な問題と して指摘されていた。

以上のように, ボランティアについては, 社会変革の 担い手とする立場と, 変革を遅らせ既存の社会構造を温 存させると考える立場の両方が並存している。このよう な両義性が発生するのはなぜか。実際のところ，ボラン
ティアは社会構造のもとでどのような役割を果たしてい るのか。その活動は, いかなる点で社会変動へとつながっ ていくのか。

これらの問題を, 本稿では, 阪神大震災を契機とする ひとつの活動を軸に検討する。以下，本稿では，阪神大 震災を契機として登場し，変遷を重祆つつ現在に至って いる，記録するボランティアの活動とその系譜に関する エスノグラフィ的記述を行う。それに基づいて, ボラン ティアの意義と社会との関わりあいを検討していく。

\section{1-2. 対象と方針}

本稿では，震災を契機として発足した記録するボラン ティア団体の活動と, その活動内容の変化, 名称変更, 分裂といった，一連の系譜をたどり報告する。本稿で取 り上げるのは，次のような記録するボランティアの系譜 である。

(1)阪神大震災地元 NGO 救援連絡会議

(2)震災・活動記録室

(3)震災しみん情報室

(4)震災・まちのアーカイブ

(5)市民活動センター神戸 (KEC)

これらは Figure 1 に示す通り, 1995 年の発災以降に発 足し, 変容・分裂した, その系譜をたどったものである。 本稿執筆の時点で活動を継続しているのは(4)と(5)であ る。この 2 団体は, 震災時に発足した団体(1)を, その祖 先としている。さらに正確に言えば, 団体(1)自身も, 後 述の通り, 阪神大震災発災以前にその起源を有している。

震災を契機とする社会の変化を考察するにあたり，記 録という限られた活動の系譜を取り上げた理由は次のと おりである。この記録活動の系譜は，後述するように， ネットワーク型の活動から始まり，そうしたネットワー クを前提として展開していった。すなわち，本団体／系 譜は, 被災地域全域にわたる多くの団体や人々と, 発災 直後から現在に至るまで, 多様な関係を保ち連携してき た。それゆえ，この系譜に着目することで，われわれは， 被災地全体の動向を視野に含めながら，社会の変化を探 索していくことができる。

もちろん, ネットワーク型の活動といっても, 被災地 域（阪神地域）の全体をくまなく網羅しているわけでは ないし，その実効性を過大評価す心゙きでもない。しかし， 震災を体験した土地で展開されてきた，ボランティアや 市民活動の動向を多分に反映しているという点を重視 し，本稿ではこれらの団体／系譜に対象を絞り込んで検 討を行った。

なお，阪神大震災における，個々の団体や活動を網羅 


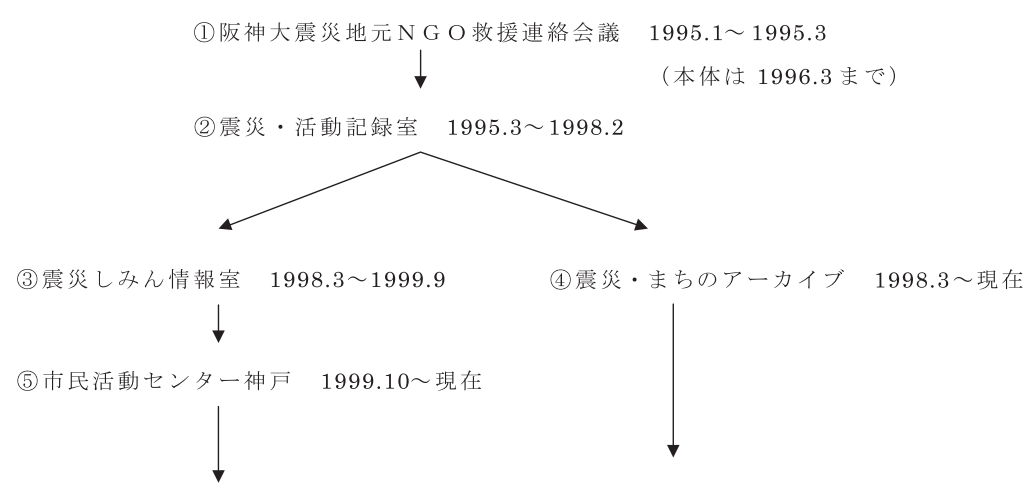

Figure 1. 本稿で検討する団体とその系譜

的に記述し，あわせて社会の変化を展望した先行研究と しては次のようなものがある。本間・出口（1996）は, 95 年の緊急救援期に定位して, 被災地で活動するボラン ティア諸団体とその活動を記述している。震災ボラン ティアの興隆は, 市民の社会参加の先駆と位置づけられ ており,「革命」にも比すべき画期的な変化, 市民社会形 成への序曲と目されている。この視点はボランティアを めぐるその後の議論の通奏低音ともなった（例えば吉永 (1999)，立木 (2001))。

山下・菅 (2002) は, 緊急救援期から復興再建期に至 るフェーズごとに, 避難所支援, 仮設住宅支援, ネット ワーキングなど, 活動領域ごとに核となった重要な団体 についての詳細な記述を行っている。ここでも, 〈ボラン ティア $=\mathrm{NPO}\rangle$ を軸とする新たな社会の到来可能性が展 望されている。ただし同書によれば，震災ボランティア の実情と, 市民社会や公共性という理念との間にはへだ たりがある。人々の結びつきを変化させ，新たな共同性 を築く可能性を示した点に, 震災ボランティアの意義が 見出されている。

西山（2005）は，同様に緊急救援期から復興期，さら にコミュニティの再生と自立までを視野に入れて, 長期 にわたり活動を継続する諸団体について記述を行ってい る。同書では, 震災を契機とするボランティア活動は, 戦後日本社会における市民活動の系譜の延長線上に位置 づけられている。震災ボランティアの体験は, この系譜 にサブシステンス（支えあい）という要素を付加し，そ れを活性化するものとみなされている。

市民社会の理念を謳いあげる議論から, 共同性の再生 に着目する考察まで, そのバリエーションと評価に相違 はあるものの, 震災ボランティアという現象——阪神大 震災を契機とする, 従前とは異なる団体と行動様式の成
立——を，社会における変化の兆候とみなす点で，これ らの論考は視座を共有している。

これらの論考と問題意識を共有したうえで，本稿では 次の問題を検討する。社会に変革をもたらすとされる活 動が, しかし同時に, 変革に抵抗し既存の社会構造を温 存する活動ともなり得るのはなぜか。ボランティアは社 会構造のもとでどのような役割を果たしているのか。そ してその活動はどのようにして社会変動とつながってい るのか。

この問題を扱うため, 本稿ではあえて, 現場での対面 的・身体的活動ではなく，そこから距離を置き記録と情 報伝達のボランティア活動に特化した団体, およびその 系譜を取り上げる。本稿では特にその長期的な変遷のプ ロセスに着目して検討を行う。いかなる状況のもとでそ の活動は求められ, 特定の団体一と結実していったのか。 その活動は, 現在まで存続するために, どのような変容 を被ってきたのか。その過程に見出される, 社会変動と 個別の活動との相互の連関を，本稿では抽出していく。

\section{1-3. 社会変動の視点}

事例記述に先立って，本稿における「ボランティア」 および「社会変動」についての概念整理を行っておく。 本稿では Moscovoci (2000) の社会的表象論を援用する。

社会的表象論の基本概念は次のようなものである。わ れわれは常に, 社会的に表象され意味づけられた現実, すなわち社会的に構成された現実のなかで生活してい る。言い換えると，われわれは膨大な社会的表象の体系 に取り巻かれて生活を送っている。

ただし，この社会的な現実は，決して固定した不変の 存在ではなく, 絶え間なく変化し続けてもいる。既存の 社会的表象の体系に含まれない新奇な（unfamiliar）事象 
が，現代社会においては絶え間なく発生し続けるからで ある。たとえば, 新しい科学知識や技術, 未知の経済現 象や宗教現象などが, 現代社会においては絶え間なく生 じ続ける。

社会的表象の体系は,こうした事柄を新しい社会的表 象として位置づけなおし, 表象の体系のうちに馴致 (familiarize) する（以上, Moscovici, 2000 に基づく)。こ のプロセスを, 震災ボランティアに即して述べると次の ようになる。

大災害の勃発は, 予期されておらず，また，生活世界 に大きな破壊をもたらしたという点で, 社会的表象の体 系に含まれない新奇な事象であった。そうした災害に際 して, 100 万を超える人々が被災地に訪れ, 自発的に救 援活動に従事したという出来事もまた, われわれの経験 したことのない新奇な事象であった。

この新奇な事象（震災を契機とする, 膨大な数の一般 人による多彩な救援活動) は, 社会的なコミュニケーショ ン過程のなかで「ボランティア」と命名され, 有意義か つ重要な活動として意味づけられていく。すなわち, 新 奇な事象は「ボランティア」として社会的に表象される。 いったんこのような社会的表象が成立し，それが流通す るようになると——すなわち,「ボランティア」という言 葉を人々が広範に使用し, そう呼ばれる実践へと参加し, あるいはそれを見聞するという経験を重ねると一一われ われは，ボランティアと呼ばれる確固たる社会的現実が あるのだという錯覚へと絡め取られるようになる。

本来は種々雑多な要素を含んだ活動であり, また, 多 くの失敗を含みつつ手探りで展開された活動は,「ボラン ティア」と呼ばれる確固たる統一的な現実, それも, 正 しい行為, 良い行為と一方的に意味づけられた社会的現 実へと変容してしまう。これが, 社会的表象の物象化プ ロセス，すなわち，社会的現実の構成プロセスである。 言い換えると，ボランティアという社会的現実が構成さ れることは, 本来そこにあった多様性や失敗が抑圧され, 一面的かつ固定的な意味づけがなされていくということ でもある。

この観点をさらに拡張して, 本稿における「社会変動」 の概念を定義する。新しい社会的現実の構成によって, 既存の社会的表象の体系の側に変化が生じた場合, 社会 変動が生じたと本稿では定義する。一方, 新しい社会的 現実が登場しても, 既存の社会的表象の体系の側に変化 が起きない場合には，社会変動は生じていないと考える (この社会変動観も, Moscovici の社会的表象論に含まれ ているものである。詳細は Moscovici, 2000; Moscovici \& Markova, 2000)。
たとえば，ボランティアという社会的現実の構成を通 して, 既存の社会的表象が組み立てなおされるなら一一 たとえば，行政体の構造や原理，その行動様式などに抜 本的な変化が生じるなら一一社会変動が生じたと考え る。それに対し，既存の社会的現実をあくまでも前提と して，その枠内にボランティアが位置づけられている場 合には一一たとえば，行政の基本的な行動様式は変わら ぬまま, 新手の労働力としてボランティアが活用されて いるだけであれば——社会変動が生じたとは考えない。

以上のような定義のもと，ボランティアという社会的 現実がどのように構成されていったか, それはいかなる 点で社会変動と結びつくものであるかを, 記録ボラン ティアの活動事例, および, そこにみられる社会状況と の関連に基づいて検討していく。

\section{2. 方 法}

ボランティアの変遷をたどるに際して，本稿では，主 としてフィールド研究から得られた記録を使用し, また 適宜文献的資料を援用した。以下，フィールドにおける 筆者自身の記録および資料収集プロセスについて概略を 述べる。

筆者は, 1995 年 2 月〜 1996 年 3 月の間, 一ボランティ アとして, 団体(1)および(2)における活動に参加し, 参与 観察に基づく観察と記録を行った（a,b）。1996 年 4 月以 降は, 定期的な直接の活動から離れ, 資料の閲覧, ミー ティング等各種行事への参加, およびインタビュー実施 というかたちで上記団体と関係を継続, 団体(4)(5)と関わ りを保ちながら現在に至っている（c）。また，関係者に 対する聞き取り調査も実施し (d), 以上の記録および収 集した資料類などに基づいて総合的なエスノグラフィを 作成した (e)。

a. 1995 年 2 月 3 月（NGO 連絡会議(1)）現地宿舎 に泊り込み活動に参加した。A6 小型ノートを常時携帯 し, 自身の行動, ともに活動したボランティアとその活 動・発話内容, ミーティングや全体会議等の日時・場所・ 参加者・主要発言要旨などを随時記録した。配布会議資 料, 廃呆された資料・リストなどもできる限り収集した。 上記記録と資料をもとに, 団体の組織と概要, 活動の内 容, および代表的な発言をまとめた, 約 20,000 字分の工 スノグラフィを作成し一部を公刊した（杉万・渥美・森・ 八ッ塚, 1995)。

b. 1995 年 4 月 96 年 3 月（震災・活動記録室(2) 週 1〜2 日の頻度で団体事務所に通勤し活動に参加した。 当初は a のノートに継続して団体構成・運営を記録した。 また，共同の資料台帳兼業務日誌（A4 用紙約 200 枚の 
ファイル）に，出勤日の活動内容，連絡のあった団体と その内容, 新規に受領した資料, 特記事項等を記入した。 それ以外に, スタッフの発言, 活動についての気づき等 を個人用ノートとして筆記記録した (A4 無地 100 枚綴メ モパッド 1 冊を使用)。また, ミーティング議事録や配 布資料等，関連資料もできる限り収集した。

c. 1996 年 4 月〜 (震災・活動記録室(2), 震災しみん 情報室(3), 震災まちのアーカイブ(4), 市民活動センター 神戸(5)）直接の活動からは離脱した。第 1 に, 記録室 (2), アーカイブ(4)に対して, 平均して2ヶ月に一回程度 の割合で資料閲覧のために訪問した。上記(1)(2)を含む， 被災地で活動したボランティア団体全般について一次資 料を閲覧検討するとともに，アーカイブ(4)の活動の様子 とその内容, 関係者の談話をノートとして筆記記録した。 第 2 に, 情報室(3), KEC (5)について, 総会ほか各種会合 への参加，記録史作成への協力等を目的に，同様に 2 ケ 月に一回程度の割合で訪問した。会合等の議事内容, お よび，団体の通常活動の様子や関係者の談話をノートと して筆記記録した。それぞれ A4 無地 100 枚綴メモパッ ド 1 冊ずつを使用した。あわせて会合等資料, チラシ類 もできる限り収集した。

d. インタビュー 上述の談話記録以外に, アーカイブ (4)と KEC (5)の中心メンバーに対して，2004 年 1 月から 2 月にかけて, 活動をふりかえる聞き取り調査を実施し た。いずれも約 1 時間半, 録音機材は使用せず筆記記録 により要旨を記録した。活動の発端, 団体分裂とその周 辺，現在の心境などを中心に，固定的な設問は設けず当 事者の自由発話により談話を収集，記録した。

e. 総合的エスノグラフィ a のエスノグラフィ,およ び, b, c の筆記記録と収集資料, d のインタビュ一記録を 使用して, 団体(1)から（5)までの系譜を記した，本稿の母 体となる約 12,000 字のエスノグラフィを作成した。作成 にあたっては, 各団体の具体的な活動内容やその雰囲気 が浮かび上がるような記述をこころがけ，代表的な活動 内容にも言及するよう注意した。団体や状況の特徵を示 す発話内容も取り入れた。また，作成にあたっては，上 記に挙げた資料のほか, 筆者の個人用日記記録, 資料へ の書き込みメモ, 各団体の報告書類, ニュースレター等 も参考とした。

総合的エスノグラフィについては, アーカイブ(4)と KEC (5)それぞれの, 複数の中心的メンバーに目を通して いただき, 内容上の誤りや表現上の問題点についてご指 摘いただいたうえ修正を行った。

\section{3. 経緯と特性 :}

\section{阪神地域におけるボランティア団体の一系譜}

本章では，先述した(1)から（5)にわたる団体系譜につい て, 活動内容と団体名称の区切り毎にその概要を述べる。 各団体の活動期間と本拠地, メンバー構成, 活動内容, 財源，および周辺の状況を基礎資料として Table 1 に示 す。以下，それぞれの団体の具体的な活動の様子と重要 な談話を,【A：各団体の成り立ちと運営】, 【B：具体的 な活動】,【C：活動上の問題点と展開】の 3 項目に分け て順に整理する。

\section{(1)阪神大震災地元 NGO 救援連絡会議}

(1995 年 1 月〜 3 月，本体は翌年 3 月まで存続 $)$

【A：成り立ちと運営】

阪神大震災発災の 2 日後, 被災地で救援活動にあたる ボランティア団体間の，相互の連絡調整を目的として発 足した。代表の草地賢一氏は, 地元の NGO で, 長らく 海外開発援助, 人材派遣 - 受け入れ等の活動に携わって きた経歴をもつ。甚大な被災の有様を見た草地氏は，全 国からの支援が殺到し「それに伴って連絡調整が必要と なってくると予感」(阪神大震災地元 NGO 救援連絡会議, 1996),「全国から来られる救援団体の交通整理をしなく てはならないと考え」(95 年 3 月 14 日ミーティングでの 発言，筆者記録 a）本団体の結成を決意するに至った。

緊急救援のための暫定的な組織として結成された。し かし，関係者のネットワークを駆使し，神戸市中央部に 電話回線 10 本をもつ事務所を確保するなど恵まれた設 備体制を整えた。緊急救援状況下, 全国からのボランティ ア初心者が入れ替わり活動に参加したため運営体制は明 確ではない。主たる意思決定は代表と少数の中心メン バーによって行われた。

【B：具体的な活動】

毎朝のミーティングで連絡事項を確認後，ボランティ アは事務所内で終日活動を行う。被災地外の一般から寄 せられる，物資提供希望やボランティア参加希望などの 電話連絡と，ボランティア団体からの，希望する物資や 必要とする人員などについての電話・FAX 連絡を取りま とめ, 相互のマッチングを行うことが主たる任務である。 これらの情報は, さらに集積され，一斉 FAX 送信などで 各団体に流される。筆者が従事したのも, 大半はこのよ うな電話取次ぎと記録作成という事務的活動であり，電 話内容記録用紙，団体連絡先一覧など，大量の記録資料 を連日使用している。

日々の活動とは別に，2 週間に 1 回程度の頻度で，被 
Table 1

本稿で検討した 5 団体の概要

\begin{tabular}{|c|c|c|c|c|c|}
\hline 団体名 & 活動期間／本拠地 & 構成メンバー & 活動 & 財源 & 周辺状況 \\
\hline $\begin{array}{l}\text { (1)阪神大震災地元 } \\
\text { NGO 救援連絡会 } \\
\text { 議 }\end{array}$ & $\begin{array}{l}1995 \text { 年 } 1 \text { 月 } \\
\sim 1996 \text { 年 } 3 \text { 月 } \\
\text { 神戸市中央区 } \\
\text { 関係者の好意によ } \\
\text { り事務所スべース } \\
\text { を無償にて間借 }\end{array}$ & $\begin{array}{l}\text { 代表： } \\
\text { 地元既存 NGO 代表 } \\
5 \text { 前 } \\
\text { 所で活動 } \\
\text { 既存 NGO 関係者を } \\
\text { 中心に運営 被災地 } \\
\text { 外からの学生・社会 } \\
\text { 人等が, 一般ボラン } \\
\text { ティアとして事務局 } \\
\text { 活動を担う。 }\end{array}$ & 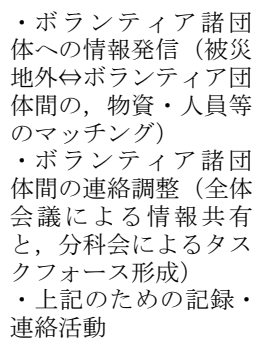 & $\begin{array}{l}\text { ·寄付金による運 } \\
\text { 営(そ他, 企業か } \\
\text { ら通信機材等の物品 } \\
\text { 提供) }\end{array}$ & $\begin{array}{l}\text { ·仮設住宅への入 } \\
\text { 居開始 (95 年 } 2 \text { 月) } \\
\text { • 仮設住宅約 } 40,000 \\
\text { 戸完成 (95 年 } 8 \text { 月) } \\
\text { 避難所 } 9 \text { 集 約と } \\
\text { 「待機所」化 (同) }\end{array}$ \\
\hline (2)震災・活動記録室 & $\begin{array}{l}1995 \text { 年 } 3 \text { 月 } \\
\sim 1998 \text { 年 } 2 \text { 月 } \\
\text { 神戸市中央区 } \\
\rightarrow \text { 長田区 } \\
\text { 関係者の好意によ } \\
\text { り事務所ス゚ース } \\
\text { を無償にて間借 }\end{array}$ & $\begin{array}{l}\text { 代表: } \\
\text { (1)の元メンバー } \\
2 \sim 5 \text { 名前後が事務 } \\
\text { 所で活動 } \\
\text { 地元の主婦・学生を } \\
\text { 中心とするボラン } \\
\text { ティアが活動を行 } \\
\text { う。 } \\
\text { 中核となる } 1 \text { 名 } \\
\text { が有給・常勤化。 }\end{array}$ & $\begin{array}{l}\text { •ボランティア自身 } \\
\text { の手による災害救援記 } \\
\text { 録資料の収集と保存 } \\
\text { (資料提供呼びかけ,整 } \\
\text { 理保存, 等) } \\
\text { •ボランテ被災 } \\
\text { 者のための記録と情報 } \\
\text { 発信 (復興住宅応募の } \\
\text { 手引き作成, 住宅周辺 } \\
\text { マップ作成, 等) } \\
\text { •NPO 法制の学習と } \\
\text { アピール }\end{array}$ & $\begin{array}{l}\text { • (1)から寄付金を } \\
\text { 受けて運営 } \\
\text { ・財団等の助成金 } \\
\text { に一部依拠 }\end{array}$ & $\begin{array}{l}\text { •復興公営住宅第 } 1 \\
\text { 次募集開始 }(95 \text { 年 } 10 \\
\text { 月) } \\
\text { • 日本海重油流出 } \\
\text { 事故ボランティア } \\
(97 \text { 年 } 1 \text { 月) }\end{array}$ \\
\hline (3)震災しみん情報室 & $\begin{array}{l}1998 \text { 年 } 3 \text { 月 } \\
\sim 1999 \text { 年 } 9 \text { 月 } \\
\text { 神戸市長田区 } \\
\rightarrow \text { 中央区 } \\
\text { 儥貸により確務。 } \\
\text { スペー }\end{array}$ & $\begin{array}{l}\text { 代表 : } \\
\text { (2)代表から継続 } \\
3 \sim 5 \text { 名前後が事務 } \\
\text { 所で活動 } \\
\text { 職務内容の専門化, } \\
\text { 中核的メンバーの有 } \\
\text { 給・常勤化が進行 }\end{array}$ & 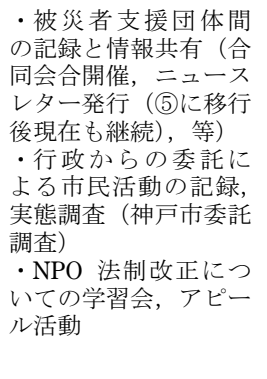 & $\begin{array}{l}\text { •寄付金と助成金 } \\
\text { による運営 } \\
\text { • 委託事業の受 } \\
\text { 託を開始。初期の活 } \\
\text { 動はノウハウが去 } \\
\text { く赤字 }\end{array}$ & 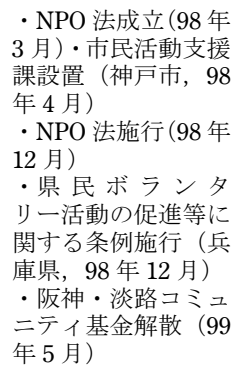 \\
\hline $\begin{array}{l}\text { (4)震災・まちののアー } \\
\text { カイブ }\end{array}$ & $\begin{array}{l}1998 \text { 年 } 3 \text { 月 } \\
\text { 〜現在 } \\
\text { 神戸市長田区 } \\
\text { (2)の本拠地を継 } \\
\text { 承, 代表者が継続 } \\
\text { してスペース提供 }\end{array}$ & $\begin{array}{l}\text { 代表 : } \\
\text { 地元経営者夫妻 } \\
\text { (2)の事務所スペー } \\
\text { スを提供, 活動にも } \\
\text { 参加) } \\
2 \sim 5 \text { 名前後が例会 } \\
\text { 形式で活動 } \\
\text { 歴史史料関係者, 研 } \\
\text { 究者, 地元学生, 地 } \\
\text { 元主婦等 }\end{array}$ & $\begin{array}{l}\text { •(2)の記録資料をは } \\
\text { じめとする震災資料の } \\
\text { 整理・保管・公開 } \\
\text { •聞き取り調を查 } \\
\text { む新たな震災資料の記 } \\
\text { 録・収集活動 } \\
\text { ・記録と記憶に関連 } \\
\text { する学習と研究活動 } \\
\text { (「戦争の記憶」, 「公害 } \\
\text { 問題の記憶」等の主題 } \\
\text { に即して) }\end{array}$ & $\begin{array}{l}\text { •寄付金と助成金 } \\
\text { による運営 } \\
\text { 自主制作の冊子 } \\
\text { 等も販売 }\end{array}$ & $\begin{array}{l}\text {-人と防災未来セ } \\
\text { ンター開館 }(02 \text { 年 } 4 \\
\text { 月) }\end{array}$ \\
\hline $\begin{array}{l}\text { (5)市民活動センター } \\
\text { 神戸 } \\
(2001 \text { 年 } 3 \text { 月より } \\
\text { 特定非営利活動法 } \\
\text { 人 (NPO 法人)) }\end{array}$ & $\begin{array}{l}1999 \text { 年 } 10 \text { 月 } \\
\text { 〜現在 } \\
\text { 神戸市中央区 } \\
\text { 賃貸により事務所 } \\
\text { スペース確保。よ } \\
\text { りアクセスのよい } \\
\text { 市内中心地付近に } \\
\text { 移転 }\end{array}$ & $\begin{array}{l}\text { 代表 : } \\
\text { (3)代表から継続 } \\
\text { (理事会·総会による } \\
\text { 運営体制が整備され } \\
\text { る) } \\
4 \text { 前後が事務 } \\
\text { 所で活動 } \\
\text { 業務内容の専門分化 } \\
\text { に伴い, 有給・常勤 } \\
\text { での活動が一般化 }\end{array}$ & 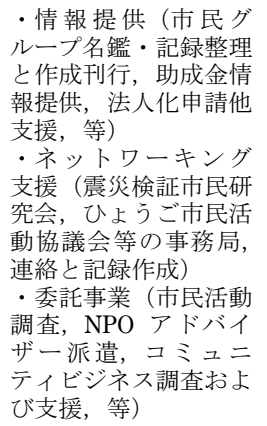 & $\begin{array}{l}\text { ·会費収入／寄付 } \\
\text { 金, 助成金, 事業収 } \\
\text { 入による運営 } \\
\text { ·会員制度の確立 } \\
\text { をはじめ, 委託事業 } \\
\text { に依存しない体制を } \\
\text { 模棠 }\end{array}$ & $\begin{array}{l}\text { • 仮設 住宅の「解 } \\
\text { 消」( } 00 \text { 年 } 1 \text { 月) } \\
\text { ·市民参画推進局 } \\
\text { 設置 (神戸市, } 02 \text { 年 } \\
4 \text { 月) } \\
\text { •ひょうごボラン } \\
\text { タリープラザ開設 } \\
\text { (兵庫県, } 02 \text { 年 } 6 \text { 月) } \\
\text { - 県民 } 9 \text { 参画と協 } \\
\text { 働の推進に関する条 } \\
\text { 例制定 (兵庫県, } 02 \\
\text { 年 } 12 \text { 月) } \\
\text { ·改正 NPO 法成立 } \\
(03 \text { 年 } 5 \text { 月) }\end{array}$ \\
\hline
\end{tabular}


災各地で救援活動にあたる団体の代表者が参加する全体 会議（1回につき $60 \sim 80$ 団体前後の代表者が参加）が 開催された。スタッフは事務局員として, 各種の連絡と, 議事録や関連情報等の記録・送信等にあたった。この全 体会議からは, 救援ボランティア諸団体のタスクフォー スである分科会が組織され, 行政管轄救援物資の利用に 関するアピール, 居住外国人支援等, 共通の課題に対処, さらなる情報交換を行った。

この間, 行政機関による救援活動は, 緊急状況の中で 後手に回らざるを得なかった。行政によるボランティア 登録はごく一部にとどまっており，「群雄割拠」（山下・ 菅，2002）するボランティア諸団体が, 各地で独自の活 動を展開した。発災直後にボランティア同士の情報交換 の場を設定し, 被災地外部との一元的な空口を設けよう とした草地氏の活動は, その実効性は別としても, 先見 的な試みとして高く評価されなくてはならない。

本稿冒頭で引用した草地氏の発言は, ミーティングや 全体会議においてなされており，一ボランティアであっ た筆者も繰り返しそれを聴取した。

「ボランティアは, 決して行政の下請けの位置に止まっ てはならず，対等の立場で企業や行政に発言できる第 3 セクター, 草の根の民主主義の担い手とならなくてはな らない」（八ッ塚・矢守（1997）より。定例ミーティン グにおける複数回の発言, 筆者記録 a)

「ボランタリズムが育っていない。言われてもしない, 言われなくてもする, という自主性がボランティアの原 則である。これまでのボランティアは，常に行政主導の 使い捨てではなかったか」(95 年 2 月 28 日全体会議での 発言，筆者記録 a)

これらの発言には, 学生など初心者も多いスタッフに 対して, ボランティアの意義を説くという趣旨も含まれ ていた。ただし, 当のボランティアには, 具体的な活動 とつながらない抽象的な議論と受け止められた面もあ る。

【C : 活動の変化】

1995 年 3 月以降, 緊急救援から, 仮設住宅支援をはじ めとする, 地域に密着した長期的な活動が求められる段 階へと状況が移行した。団体内部では, 必ずしも十分な 連絡調整ができておらず，現場の実態から遊離している のではないか, といった問いが発せられるようになって きた。その後, NGO 連絡会議11の活動は仮設住宅支援へ と特化していった。そこから派生した「被災地 NGO 恊 働センター」が連絡会議(1)の活動を引き継ぎ現在に至っ ている。連絡会議(1)の活動の詳細については, 杉万・渥 美・森・八ッ塚 (1995), 本間・出口（1996）にも詳しい。
なお，活動をリードした草地氏は 2000 年 1 月急逝され た。氏の活動系譜や理念は『草地さんの仕事』刊行委員 会（2001）に詳しい。

(2)震災・活動記録室（1995 年 3 月末～ 1998 年 2 月）

【A：成り立ちと運営】

NGO 連絡会議(1)のボランティア問題分科会は, 95 年 3 月上旬, ネットワーク参加 120 団体の活動実態調查を 実施した（震災・活動記録室（1995）所収）。この調查 がきっかけとなり，連絡会議(1)のメン゙ーを中心に，震 災における救援活動の記録と資料収集を目的とした本団 体が結成された。

この時期，緊急救援は収束に向かい，仮設住宅の建設 など，行政による長期的支援活動が本格化していった。 ボランティアの側も, 仮設入居者への支援等, 地域に密 着した長期的な活動に移行するか，被災地から撤収する かの決断を迫られるようになった。震災体験の風化が話 題に上るようになったのもこのころである。

そうした状況の中, 緊急救援時の貴重な体験が失われ 散逸する，という眯念や，もっとうまく活動できたはず だ，という反省の念から，ボランティアによる救援活動 を記録に残そうという運動が具体化していった。

震災資料を収集保存しようという活動は，発災直後か ら多方面で展開されていた。研究者を中心とした「歴史 資料ネットワーク」(小山（1995)，奥村（1995））や，県 の委託事業として「21世紀ひょうご創造協会」によって 行われた資料収集活動などはその代表例である。しかし， 史料保存の活動を担う行政の恒常的施設（通称「メモリ アルセンター」）が，「人と防災未来センター」として開 館するのは 2002 年のことである。行政でも研究者でも ない, 救援活動を行ったボランティア自身が，極めて早 い時期に震災資料の収集と保存を開始したことは注目す ベきである。

当初は連絡会議11の一部門として活動していたが，実 質的な活動内容の分化や連絡会議(1) の批判などから, 95 年 9 月, 正式に分離独立した。代表の実吉威氏は, 企 業勤務経験をもつ自由人で, 阪神大震災を契機に連絡会 議(1)の活動に参加した。他のメンバーも, 学生や地元の 主婦など，震災をきっかけに初めてボランティアに参加 した人々が多い。活動方針の決定等は，延べ 10 人前後 のメンバー全員による, 毎週のミーティングで行われた。

【B：具体的な活動】

事務所内での活動と, 対外的な活動とに分けられる。 ボランティア・救援活動の資料収集という趣旨を, シン ポジウムや報道で広く周知した結果，諸団体の撤収時期 
と重なったこともあって, 被災地全域から, 予想を超え る数の記録資料類が自発的に提供された。個人のボラン ティア体験記, 撤収した団体の活動報告書, 諸団体の ニュースレターやチラシ等, 3 ケ月で 400 点以上が寄せ られている。このため, 日々郵送される資料を整理・分 類し, 公開できるかどうかを調べる純粋な事務処理の作 業に大きな労力が必要となった。

その一方で, 連絡会議(1)時代一の反省から, 実際に現 場で活動してきた人々との関係づくりも重視された。当 初は毎週 1 回のペースで, ボランティアの声を記録する インタビューが実施され, 震災時の活動経緯などを記録 していった。さらに, 活動を継続する団体一の取材や情 報收集, ボランティア同士の各種会合への参加など「外 回り」も活発であった。あわせて, 資料提供の呼びかけ や, ボランティア同士の情報交換, 被災地の状況の発信 などを目的としてニューズレターが刊行され， 1 年間で

20 号を数えた。

\section{【C : 活動の変化】}

内外からの批判と困難に遭遇し, 活動内容が変化して いった。一方では，記録資料の公開を目指す活動が，プ ライバシーの問題に直面して停滞していった。訪問記録 や日誌などといったボランティアの活動資料には, 個人 名や住所だけでなく, 被災者の家族構成や病歴など, 私 的な情報が数多く記録されている。このような記録資料 の公開方法や，そもそも公開できるのかという問題につ いて, 容易には答えを見出せず，資料を扱う活動は一時 停滞した。「これは, 大変な問題だと思いました。内部で も随分議論をしました。でも自分達では, 答は出ません でした」(実吉氏の回想, 筆者記録 $\mathrm{c}$ ，および，震災・ま ちのアーカイブ (2003))。

他方で, 被災地の中心にいながら「記録」をめぐる「事 務仕事」に携わる活動の姿に,「信じられない」「苦しん でいる人々がまだまだたくさんいるというのに何を考え ているのか」といった厳しい批判が, 外部の人々から投 げかけられた（96 年 1 月 27 日, 震災救援に取り組む医 師やボランティアを招いての学習会における参加者の発 言, 筆者記録 $\mathrm{b})$ 。メンバー自身も, 被災地と人々の役に 立つ活動をす心゙きではないのかと自問するようになる。 ニューズレターにおいても,「仮設住宅の内と外」「深刻 な〈住〉の問題」（記録室通信 17 号，1996 年 3 月）等, 被災地の現状や人々の声を中心に, 取材や報告, 提言が 多く扱われるようになっていった。

発災から 1 年半, 復興住宅の募集が拡大していった時 期, 行政発行の複雑な申込書面を解説した「復興住宅応 募の手引き」を作成・配布し相談を受け付けるなど, 被
災者自身に対する情報発信の活動を展開した。完成して いった復興住宅については, 近隣の店舗, 医療機関等の 情報を記録記載した「マップ」作成の活動を行った。こ の活動は地域で支援活動にあたる団体からも歓迎され た。

さらに, 災害救援以外の市民的活動（福祉，国際交流， 地域活動等々）全般について, 兵庫県下のグループ・団 体を網羅的に記録したダイレクトリ『グループ名鑑「兵 庫・市民人」'97』(市民活動地域支援システム研究会・ 神戸調查委員会（1997））の作成に携わるなど，地域の 活動それ自体を支援する記録活動を展開していくように なる。後の NPO 法制につながる, 学習会や情報発信の 活動も動き出すようになった。

こうして徐々に, 行政による支援活動や通常の報道か らは漏れ落ちるような, 多彩な領域への支援へと関わっ ていくようになった。やがてそこから, 地域で活動する 団体に対する支援，すなわち中間支援という方針が明確 に形を結ぶようになっていく。

これらの動きは, いずれも行政体に先んじるものでも あった。地域で活動する団体一の支援が，行政の明確な 方針として打ち出されるようになるのは 98 年度以降の ことである。

他面, 独自の活動を発見していく過程で, 震災体験を 記録し継承する活動と, 被災地で暮らし活動する人々の ための活動は，大きく分化していくことになった。活動 方針をめぐる議論を経て, 最終的に記録室(2)は分裂の道 をたどった。

活動前半の詳細は, 震災・活動記録室（1995）にまと められている。また代表の実吉氏自身による活動経緯の 回想として, 震災・まちのアーカイブ（2003）がある。

(3)震災しみん情報室（1998 年 3 月～1999 年 9 月）

(5)市民活動センター神戸 (KEC/Kobe Empowerment Center)

(1999 年 10 月〜現在)

【A：成り立ちと運営】

1998 年 3 月, 情報発信活動を担うスタッフが, 神戸市 長田区内で新事務所に移転したのを契機に，震災・活動 記録室(2) 2 つの団体へと分裂した。実吉氏を代表とし て, 被災者やボランティアに対する情報提供を主たる活 動に謳った団体が，震災しみん情報室(3)である。当初は 被災者・住民一の情報発信に力点が置かれていたが, や がて，ボランティア・NPO 団体への支援，すなわち中間 支援へと特化していった。

1999 年 10 月, 神戸市中央区一の移転を契機に名称を (5)に変更, 2001 年 3 月, 特定非営利活動法人となった。 
定款が策定され, 総会・理事会・事務局という, 意思決 定と運営の体制も整備された。代表を務めてきた実吉氏 が事務局長, のち理事長となり, 常勤専従スタッフとと もに活動を主導している。また, NGO 連絡会議(1)の事務 局長代行であった中田豊一氏が初代理事長となるなど, 震災以降関わりを持ってきた NGO 関係者, 研究者ほか, 有力メンバーが理事に名を連ね運営に示唆を与え続けて いる。筆者自身は日々の直接的な活動には携わっておら ず，会合等への参加などで関係を保っている。

\section{【B：具体的な活動】}

常に複数の常勤スタッフの姿がある活発な事務所とし ての様相を見せる。各種の助成金情報や書式の作成方法 など, 団体運営に不可欠の情報の提供, 法人申請や経理 についてのコンサルティング，イベントや会合などの情 報交換等々, 阪神地域で活動する団体の情報センターと して, 多様な問い合わせに対応している。電話での問い 合わせや来訪者の面談など, 連絡と人の出入りが絶えな い。

こうした日常業務と平行して，多くのプロジェクトが 同時進行しており, そのための事務作業も繁多となって いる。市民活動グループ名鑑（市民活動センター・神戸 （2000）など）作成のための調査記録活動, ニュースレ ター刊行のための取材や原稿作成, 原稿依頼などはその 典型である。さらに，ボランティアや市民団体のネット ワーキングを支援し，その事務局機能を担当しているた め, 会合のための関係者の日程調整から, 資料の作成や 記録配布に至るまで, スタッフは地道な連絡調整の作業 に追われている。

他方, 実吉氏をはじめとする中核的なメンバーは, 阪 神地域外部の団体・ネットワークとの交流や, 各種の研 究会参加, 講師依頼, 行政関係者との会合, さらには $\mathrm{NPO}$ 法制関連の研究とアピール等, 対外的活動にも多く の時間を割いている。

直接的な資料保存の活動からは遠ざかっているもの の, 市民活動団体やその申請書類, ニュースレターと情 報伝達など，記録という活動はその骨格にあり続けてい るといえる。

\section{【C : 活動の変化】}

常勤職員の数や, 神戸市中心部の利便性の高い事務所 など, 阪神地域でも有数の規模と知名度を持つ団体とな りつつある。その掲げる理念や, 情報提供活動の有用性 についても, 周辺の理解や評価は高い。また, 行政から の委託調査事業や, NPO アドバイザー派遣事業（緊急雇 用対策の一環としての, NPO への人材派遣事業), コミュ ニティビジネス支援事業（情報提供等による起業支援）
など，重要な事業を担ってきたことから，予算面の充実 だけでなく, 組織としての知名度や影響力も増大して いった。

この間，行政の動きに常に先んじて，また実質を伴う 活動を展開してきたことは，疑い得ない事実である。い わゆる「市民参画」や「市民との協働」を，行政体が政 策として掲げ，曲がりなりにも具体的な動きを見せるよ

うになるのは, 2002 年以降のことであった。

他面, 団体の内部では運営方針の模索が続いている。 行政からの委託事業に多大な作業時間を取られたため, ニュースレター刊行に大幅な遅延が生じたことなどは, 大きな反省材料となっている。委託事業に過度に依存せ ず, 独自の調查・アドボカシー活動を展開していくため の体制づくりの努力が続いている。

情報室(3)時代を代表自身が記した著作に実吉（2000） がある。また, 震災復興市民検証研究会（2001）にも経 緯の記述がある。

\section{(4)震災 · まちのアーカイブ（1998 年 3 月〜現在）}

\section{【A：成り立ちと運営】}

記録室(2)に事務所スペースを提供していた季村敏夫 氏・季村範江氏夫妻を中心に, 研究者, 歴史史料関係者, 地元主婦などからなるゆるやかなグループとして運営さ れている。記録室(2)の活動が情報発信へとシフトして 行ったため, 当初は「残りの資料を整理して活動を終え るつもりだった」（季村範江氏，04 年 1 月 18 日，筆者記 録 d)。活動を継続することになったのは, 外部から，そ の活動と資料の価值を指摘され，メンバー自身がそれを 再認識したことによる。

阪神地域では, 震災で被災した地域資料, 歴史資料の 整理・保存活動が, 研究者や図書館関係者などのボラン ティア的活動によって早い時期から展開されていた。こ れらの活動は, 震災資料（震災体験手記，ボランティア 活動記録，ビラ，チラシ等の文書的一次資料等）そのも のを歴史資料として収集・保存しようという動きへと広 がっていった。

こうした活動に携わっていた実務担当者や研究者の一 部が資料の価值を発見，新たなメンバーとなったことか ら, 活動は変化していった。第一に, 震災資料は貴重な 歴史史料であり，それらを収集・保存すること自体に大 きな意味がある, という視点が, 活動の中に導入された。 第二に, 研究機関でも行政機関でもない, ごく普通の人々 の手によって, 震災資料を収集・保存することの重要性 が，メンバーに自覚されるようになった。日本では類例 の乏しい「市民による文書館（アーカイブ）」として, 地 
域の中で震災の記憶を担い, コミュニティとその文化の 礎を築いていくという方針がメンバーに共有された。

筆者自身は活動には従事していないが，記録資料の閲 覧・調查のため, 事務所訪問を繰り返している。

\section{【B：具体的な活動】}

月に数回活動日が設定され, 参加したメンバーで作業 が行われる。通常は事務所で, 記録室(2)時代の収集記録 資料や，新たに寄贈された資料の，整理と目録づくり， 電子化のための情報入力作業などが淡々と進められてい る。活動日誌, 報告書, ニューズレター, 物資や金銭の 出納記録, 訪問記録, ボランティア体験手記など, 資料 の種類は多岐にわたっており, 資料はひとつの団体だけ で段ボール数箱にのぼることもある。資料の閲覧を希望 する研究者, 新聞記者等への応対も随時行われている。

記録資料に関わる活動のほか，特に近年は，聞き取り 調查, 研究会, 展示などにも力が注がれている。戦争の 記憶, 公害問題の記録と伝承, 歴史的な災害等々, 幅広 いテーマについて, 学習会やインタビューなどが実施さ れている。また, これらの成果をブックレット等で刊行 する活動も行っている。

【C：活動の変化】

国と県の出資による阪神・淡路大震災記念施設「人之 防災未来センター」が開館したのは, 先述のとおり 2002 年のことである。その構想段階から, アーカイブ(4)は, 震災資料の収集を重視しそのための専門職員を充実させ ることや，一般市民に対しても積極的に資料を公開する ことなど, 施設と展示のあり方をめぐる訴えを続けてき た。日常の活動それ自体が，記憶と記録をめぐるひとつ の実践事例となっていたともいえる。

近年では, 研究助成金を得て, 記録と記憶をめぐる フォーラムや展示を催すなど, 対外的な表現の活動にも さらに力を注ぐようになっている。記録活動を前提に, 発信への模索が行われている。

\section{4. 考察}

\section{4-1. 社会変動との関連からみた活動の系譜}

本章では, 記録するボランティアの変遷と分裂の過程 を, 被災後の社会状況の変化と対応づけながら整理し, ボランティアとその意味を検討する。本節では, 社会構 造のなかのボランティアの位置づけとその変化を概観す る。次節では, 記録という活動がどのような意味を持っ ており,それが社会変動とどう結びつくのかを考察する。

(1)発災直後〜被災に対応した新しい活動としての記録 ボランティア

NGO 連絡会議(1), ボランティア間の連絡調整とネッ
トワーキングを目的とし，そのために記録活動に特化し た団体である。被災規模の大きさと，それに伴う前例の ない規模の救援活動の展開が, それに対応した救援活動, すなわち，ネットワーキングと情報交換の活動を必要と した。その役割を担ったのが連絡会議(1)であった。端的 に言えば, 被災地で活動する膨大な数のボランティアの ために連絡調整のボランティアを行うこと，それが連絡 会議(1)活動であったといえる。その活動は, 現場で直 接人々に対処するのではなく, 事務所のなかで帳簿やリ ストをつけ記録を行うものであった。

このような記録の活動は，発災直後の段階においては その必要性が理解され一定の支持や参加者を集めた。す なわち，ボランティアという社会的表象のうちに含まれ る活動として社会的に受容されていたと考えることがで きる。活動に従事寸るボランティア自身も梁刻な違和感 には遭遇していなかった。しかし, 緊急救援段階の収束 に伴って, 緊急救援に対応した記録とネットワーキング はその必要を減じさせていく。それに伴って連絡会議(1) の活動も変化し終了へと向かっていった。

(2)緊急救援の収束とボランティアの撤収〜記録ボラン ティアへの特化と批判

震災・活動記録室(2)は，震災救援ボランティアの活動 記録や資料を保存することに特化した活動である。阪神 大震災は, 既存の社会構造全体を肙か寸衝撃的な出来事 であった。しかし, 復旧が進み, 社会的現実が回復して いくなかで, その衝撃性や新奇性は薄れていく。言い換 えると, 平穏な社会的現実の復帰に伴い, 過去の出来事 として震災を位置づけるという, 社会的な忘却のプロセ スが進展したのだと考えることができる。

そうした情勢に対するボランティアの反応が，記録室 (2)の活動を生み出寸ことになった。個々のボランティア は, 多くの失敗や模索を重祆ながら, 被災地で多彩な手 探りの活動を展開してきた。しかし，そうした活動は， 「過去の活動」「良い活動」「有用な活動」という一面的な 評価を与えられ，ひとくくりに歴史的出来事一と追いや られようとしている。

このような社会構造の圧力に対抗し, ボランティアの 実相——その多彩な個別の活動や, 多くの模索と失敗 ——を記録し保存することが，記録室(2)の活動の本質で あった。その必要を多くのボランティアが共有していた からこそ，記録室(2には大量の記録資料が寄せられたの だと考えることができる。

しかし，被災地の内部では，記録室(2)の活動に内在的 な困難が生じ，また強い批判が寄せられるようになって いく。困難や批判もまた, 社会構造との関連で生じたも 
のである。

記録室(2)の収集した資料は，震災という緊急時に記録 されたものである。しかし，緊急時に記録された極めて 個人的な情報は, 回復しつつある社会的現実のもとでは, プライバシーを劦か寸, 取り扱い困難な危険物ともなる。 他方で, 被災地の内部から見れば, 未だ困難な状況に置 かれている人々がいるにも関わらず記録に徹する活動 は, 現実から遊離した活動と受け取られざるを得なかっ た。

復旧のプロセスが進む中で, ボランティアという社会 的表象もまた固定化していったのだと, これらの出来事 の背景を推測することができる。ボランティアは, 対面 的な直接的支援の行為, 単純な良い行為, といった意味 あいで社会的に表象され，またそうしたリアリティが定 着していった。それゆえに, 記録室(2)の活動——現場か ら距離を置く一方, プライバシ一等にあえて抵触する危 険性をも含んでいる——は, 批判と困難に遭遇したのだ と考えることができる。

記録するボランティアの活動は, 復旧が進み社会的現 実が回復していくプロセスにあって, 社会の側に居場所 を見出せず，また被災地の側にも受け入れられない，宙 吊りの状態に陥った。自身の活動の意味を見失った活動 は，しかし，2つに分裂することによって，新たな目的 と活力を得ていくことになる。

(3)(5)被災後の社会への発信〜記録から中間支援活動 の進化

記録室(2)の活動は 2 方向に分裂する。一方は, 震災し みん情報室(3), 市民活動センター神戸(5)の方向, すなわ ち，ボランティアへの情報発信と中間支援という方向に 記録の活用をシフトすることであった。

震災と救援ボランティアの経験を踏まえて, 現代社会, すなわち既存の社会的現実の中で活動する団体や個人を 支援し，市民による社会的活動を支援していくこと。そ れが KEC (5)の理念である。記録するという活動を, リ アルタイムで進行するボランティアの活動に限定し, そ れに関する整理や情報発信といった支援に特化すること が，KEC (5)の採った方針であった。

社会構造との関係においてみれば,この活動は次のよ うな意味を有している。ボランティアは，直接的な支援 行為, 善行として社会的に表象される。それゆえ, 本稿 冒頭で述べたように，無償の労働力として活用しようと いう傾向にも巻き込まれがちとなる。それに対して, 自 立した市民的活動としてその財政的・組織的基盤を確立 し，また互いの情報交換と連携によって活動を豊かにし ていくことが KEC (5)の目的である。
すなわち，既存の社会構造に対して，独自の基盤と存 在感をもつ領域として, ボランティアと市民の活動を根 付かせようとする試みが KEC (5)の活動である。そのた めに，記録する活動に特化してネットワーキングの拠点 となっていることに大きな特徴がある。

ただし，ここでいう拠点は，あくまでも多彩な団体の 結節点に過ぎない。地域の中心に立つとか, 諸団体の連 合の主導権を握るなどといった志向性は，ここには見ら れない。筆者の問いに答えて, 実吉氏は次のように現在 の活動の方針と自身の関心を語っている。

「別に majority にならなくていい。みんなが関心をもた ないもの。 minor な存在であり続けてもいいよなあと思 う」

「(行政と市民）両方のことばが聞こえてしまう」

「媒介，仲介がわりと好きなんだわ」（以上，2004 年 2 月 1 日，筆者記録 $\mathrm{d}$ )

KEC (5)の活動は, あくまでも記録する活動に徹してい る。すなわち，現場で活動する諸団体に寄り添い，その かたわらで資料作成や情報交換にあたり，他団体や行政 との回路を開くという, 記録と媒介の活動に特化してい る。しかし，記録するボランティアという活動は，被災 地域において, 重要な活動として認識・受容されている。 すなわち，ボランティアという社会的表象のうちにひと つの地位と存在感を占めるようになっている。

(4)未来への発信〜被災体験それ自体の記録と伝達 その反対に，歴史的な記録それ自体に特化するという 方向を選択したのが震災まちのアーカイブ(4)であった。 アーカイブ(4)は，震災とボランティアについての記録を 歴史的資料と位置づけ，その保存と伝達を活動の中心に 置いた。

この活動は，既存の社会構造に対して震災体験を対置 しようとするものである。すなわち，震災体験を過去の 事象にしてしまおうとする現代社会の圧力に対し，証拠 としての記録資料を保存・継承し続けようとする。

ただし，注意すべきことは，アーカイブ(4)の活動が， 単純な「記憶の伝承」「風化への抵抗」を企図したもので はないという点である。季村氏やメンバーは，筆者の問 いに答えて, 活動をめぐる現在の思いを次のように語っ ている。

「風化は風化なんだから，忘れてもいいじゃない」

「必要がなくなったら, やめてしまったらいいと思って いる」

「ちがうメンバーが集まったら,またちがう活動をすれ ばいい」(以上，2004 年 1 月 18 日筆者聞き取り）

ここでは，正しい過去や正しい記憶があるのだとは想 
定されていない。また，自分たちが記録に対して特権的 な関係や使命を持っているという姿勢は感じられない。 その反対に, アーカイブ(4)の活動は, 記録資料を将来に 伝達すること，ただそれだけに限定されている。記録を どう読み解くか，あるいはそもそも保存し続けるかどう か自体，後の時代の人々の決断へと託されている。

アーカイブ(4)の活動もまた，記録することそれ自体に 徹していると考えることができる。すなわち, 貴重な震 災記録のかたわらに寄り添い, それを残していくという， 記録と媒介の活動に特化している。しかし, 記録するボ ランティアとしての活動は, 被災地においても存続し続 けている。すなわち，ボランティアという社会的表象と してその存在を確立させつつある。

\section{4-2. ボランティアによる記録活動の意義と社会変動への 可能性}

以上の検討を踏まえて, ボランティアによる記録活動 の特徵とその意義を 3 点に分けて整理するとともに, 社 会変動との結びつきを考察する。

第 1 に, 記録するボランティアは, ボランティア自身 がボランティアを対象として活動するという複合的な構 造をもっている。自分たちの活動を自分たちで記録し， 検討・改変しあるいは発信していくといった複合性, 反 省性を，記録するボランティアはボランティアの世界に 持ち込んでいるといえる。

第 2 に, このような記録活動は, 既存の社会的現実に 対する独自の関わり方を切り開いているといえる。一方 では, KEC (5)のうに, 市民的活動の基盤を広げ, 団体 間や対行政間などの新しい連携を模索するというかたち で，記録の活動が展開されている。他方では，アーカイ ブ(4)のうに，歴史を振り返り既存の現実を問い直すた めに，その基盤づくりとして記録の活動が展開されてい く。いずれの記録活動も, 自らが中心, 主体となるので はなく，記録を通した媒介と伝達の活動として展開され ている点に大きな特徴がある。

第 3 に, 記録と媒介・伝達の活動は, それ自体が, 既 存の社会構造に異議を申し立て, 新たな価值を提示する 活動ともなっている。KEC (5)は, ボランティア同士，あ るいは市民と行政の間の, 新たな結びつきのあり方を提 示し，そうした連携を促進していこうとする。アーカイ ブ(4)は, 正しい記録や記憶を主張するのではなく, むし ろ, 記録それ自体を保存することで, 多彩な読みや記憶 を支えていこうとしている。記録する活動は, 既存の社 会的現実に単純に反抗するのでもなければ, それに飲み 込まれるのでもない, 異なる可能性, 異なる現実を樹立
することを模索し続ける。

改めて整理すると, 記録するボランティアは, 社会的 現実の中で, 反省的かつ複合的な活動として, 独自の存 在感を発揮しつつある。さらに, 行政体をはじめ, 既存 の現実に対する新たな関係を模索し, 従来と異なる価值 観を生成しょうとしている。これらの点で, 記録するボ ランティアの活動は, 社会変動への可能性（あくまで可 能性ではあるが）につながっている。このような可能性 は，記録すること，すなわち，媒介と伝達に徹すること によって切り開かれたものであった。

翻ってみると，記録室(2)の場合には，記録のもつ媒介 と伝達という側面を十分に展開できていなかったと考え ることができる。むしろ,「ボランティア」という既存の 社会的表象に制約されて, 活動の可能性を狭めてしまっ たことが，記録室(2)の停滞につながったのだと考えられ る。

この問題を，ボランティア一般をめぐる問題に拡張す ることも可能であろう。一方では, ボランティアの活動 は，それまでなかった新たな活動や結びつきの可能性を 提示し, 社会構造, すなわち社会的表象の側に変化を迫 る。しかし他方で, 既存の「ボランティア」という社会 的表象が支配的となり，新しい可能性を制約する場合も ある。本稿冒頭で述べたボランティアの両義性は, この ような社会的表象の構造に由来している。社会変動の将 来を確言することはできない。しかし，記録するボラン ティアという新たな活動は曲がりなりにも存続して周囲 にも影響を与えており, 変化への可能性を示している。

もとより本事例は, 阪神大震災後のボランティアの, それもごく一部を追跡したものに過ぎない。しかし，記 録という活動の発生プロセスと, 社会状況のもとでのそ の変化と存続プロセス, および社会変動との結びつきを 本稿では検討してきた。記録し媒介・伝達を行うことは, 社会構造からの圧力に抗し, 逆に社会の側に変化をもた らしていくためのひとつの手段となり得る。ボランティ ア・市民活動一般にとっての, 記録することの意味, 書 くことの可能性を検討することが, 今後のさらなる課題 である。

\section{謝辞}

関係諸団体の皆様, 杉万俊夫先生 (京都大学), 審査者 の先生方にお礼を申し上げます。

\section{引用文献}

阪神大震災地元 NGO 救援連絡会議（1996）. 大きなうね りへ〜阪神大震災地元 NGO 救援連絡会議の 13 个月 
13 日

本間正明・出口正之（編）（1996）。ボランティア革命 東 洋経済新報社

実吉 威 (2000). 神戸，市民活動点描一市民団体スタッ フの日誌風随想録一 実験社会心理学研究, 39, 197-203.

経済企画庁（編）（2000）。平成 12 年版国民生活白書 ボ ランティアが深める好縁

小山仁示（1995）。被災史料救済活動の意義 地域史研 究一尼崎市立地域研究史料館紀要一, 25(1), 3-6.

『草地さんの仕事』刊行委員会 (2001). 阪神大震災と国 際ボランティア論 草地賢一が歩んだ道 エピック

Moscovici, S. (1984). The phenomenon of social representation. (In) R. M. Farr \& S. Moscovici (eds.), Social representations. Cambridge University Press. (In) S. Moscovici (G. Duveen (ed.)), (2000) Social Representations: Explorations in social psychology. Cambridge: Polity Press. 18-77. (八ッ塚一郎（訳）「社会的表象 という現象」, 未公刊, 下記に掲載

http://www.educ.kumamoto-u.ac.jp/ yatuzuka/ moscoSR.html, http://www.users.kudpc.kyoto-u.ac.jp/ $\sim$ c54175/index.htm)

Moscovici, S., \& Markova, I. (2000). Ideas and their development: A dialogue between Serge Moscovici and Ivana Markova. (In) S. Moscovici (G. Duveen (ed.)), Social representations: Explorations in social psychology. Cambridge: Polity Press. 224-286.

中野敏男 (2001). 大塚久男と丸山真男 動員, 主体, 戦 争責任 青土社

西山志保 (2005). ボランティア活動の論理一阪神・淡路 大震災からサブシステンス社会へ一 東信堂

奥村 弘 (1995). 歴史資料保全情報ネットワークの活動 地域史研究一尼崎市立地域研究史料館紀要一, 25(1), 7-14.

市民活動センター・神戸 (2000). ひょうご市民活動応援 ガイド グループ名鑑 2000

市民活動地域支援システム研究会・神戸調查委員会
(1997)．グループ名鑑「兵庫・市民人」’97

震災復興市民検証研究会 (2001). 市民社会をつくる 震

後 $\mathrm{KOBE}$ 発アクションプラン市民活動群像と行動計

画 市民社会推進機構

震災・活動記録室 (1995)。「震災・活動記録室」中間報告 震災・まちのアーカイブ（編）（2003）。アーカイブ前史 杉万俊夫 ・渥美公秀・森永 寿・八ッ塚一郎 (1995). 阪 神大震災におけるボランティア組織の参与観察研究 一西宮ボランティアネットワークと阪神大震災地元 NGO 救援連絡会議の事例一 実験社会心理学研究, 35, 218-231.

立木茂雄（編）（2001）。ボランティアと市民社会 公共 性は市民が紡ぎ出す 増補版 晃洋書房

山下祐介・菅磨志保 (2002). 震災ボランティアの社会学 $\langle$ ボランティア $=\mathrm{NPO}$ 社会の可能性〉 ミネルヴァ書 房

山内直人 (2002). NPO の時代 大阪大学出版会

Yatsuzuka, I. (1999). The activity of disaster relief volunteers from the viewpoint of social representations: Social construction of Borantia(volunteer) as a new social reality after the 1995 Great Hanshin Earthquake in Japan. (In) T. Sugiman, M. Karasawa, J. Liu and C. Ward (eds.). Progress in Asian Social Psychology, Volume 2. Seoul: Kyoyook Kwahaksa, 275-290.

Yatsuzuka, I. (2003). "Service” and "volunteer activity" from the viewpoint of social representations: before and after the 1995 Great Hanshin Earthquake in Japan” Abstracts of the 50th Conference of the Japanese Group Dynamics Association, 286-287.

八ッ塚一郎・矢守克也 (1997). 阪神大震災における既成 組織のボランティア活動一日本社会とボランティア の変容— 実験社会心理学研究, 37, 177-194.

吉永 宏 (1999). 響きあう市民たち NPO とボランティ ア入門 新曜社

全国社会福祉協議会 (2004). ボランティア活動年報 2003 年 


\title{
Recording volunteer activities after the Great Hanshin Earthquake and their transition: their functions and possibilities from the viewpoint of social change
}

\author{
ICHIRO YATSUZUKA (Kumamoto University)
}

Cases of volunteer activities after the 1995 Great Hanshin Earthquake in Japan were studied. Examples and genealogy of five volunteer organizations were reported, through recordings made of their activities, such as gathering and transmitting information in the disaster stricken area. The functions and implications of these volunteer activities were discussed from the viewpoint of the Theory of Social Representations. During the reconstruction process from disaster, some volunteer activities lost much of their purpose, and difficulties were encountered. The volunteer organization being studied was split into two distinct factions, and only then were they able to find their purpose and realize the meaning of these activities. The process illustrated the intermediary supporting model as seen through volunteer activities, and recordings of civil archives on disaster experiences. The potential for social change which might be brought about by such recording activities were discussed.

Key Words: volunteer, social change, social representations, recording activities 